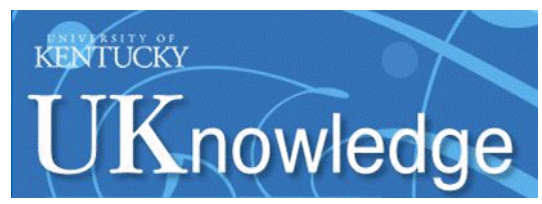

University of Kentucky

UKnowledge

8-1-2014

\title{
Persistent Hepatic Structural Alterations Following Nanoceria Vascular Infusion in the Rat
}

\author{
Michael T. Tseng \\ University of Louisville \\ Qiang Fu \\ Guang Dong Pharmaceutical University, China \\ Khoua Lor \\ University of Louisville \\ G. Rafael Fernandez-Botran \\ University of Louisville \\ Zhong-Bin Deng \\ University of Louisville
}

See next page for additional authors

Follow this and additional works at: https://uknowledge.uky.edu/chemistry_facpub

Part of the Chemical Engineering Commons, Chemistry Commons, and the Pharmacy and Pharmaceutical Sciences Commons

Right click to open a feedback form in a new tab to let us know how this document benefits you.

\section{Repository Citation}

Tseng, Michael T.; Fu, Qiang; Lor, Khoua; Fernandez-Botran, G. Rafael; Deng, Zhong-Bin; Graham, Uschi M.; Butterfield, D. Allan; Grulke, Eric A.; and Yokel, Robert A., "Persistent Hepatic Structural Alterations Following Nanoceria Vascular Infusion in the Rat" (2014). Chemistry Faculty Publications. 188. https://uknowledge.uky.edu/chemistry_facpub/188

This Article is brought to you for free and open access by the Chemistry at UKnowledge. It has been accepted for inclusion in Chemistry Faculty Publications by an authorized administrator of UKnowledge. For more information, please contact UKnowledge@lsv.uky.edu. 


\section{Persistent Hepatic Structural Alterations Following Nanoceria Vascular Infusion in the Rat}

Digital Object Identifier (DOI)

https://doi.org/10.1177/0192623313505780

Notes/Citation Information

Published in Toxicologic Pathology, v. 42, issue 6.

Tseng, M. T., Fu, Q., Lor, K., Fernandez-Botran, G. R., Deng, Z.-B., Graham, U., Butterfield, D. A., Grulke, E. A., \& Yokel, R. A. (2014). Persistent hepatic structural alterations following nanoceria vascular infusion in the rat. Toxicologic Pathology, 42(6), 984-996. Copyright @ 2014. DOI: https://doi.org/10.1177/

0192623313505780

The copyright holder has granted the permission for posting the article here.

The document available for download is the authors' post-peer-review final draft of the article.

\section{Authors}

Michael T. Tseng, Qiang Fu, Khoua Lor, G. Rafael Fernandez-Botran, Zhong-Bin Deng, Uschi M. Graham, D. Allan Butterfield, Eric A. Grulke, and Robert A. Yokel 


\section{Persistent hepatic structural alterations following nanoceria vascular infusion in the rat}

Michael T. Tseng ${ }^{\mathrm{a}}$, Qiang Fu ${ }^{\mathrm{b}}$, G. Khoua Lor ${ }^{\mathrm{c}}$, Rafael Fernandez-Botran ${ }^{\mathrm{d}}$, Zhong-Bin Deng ${ }^{\mathrm{e}}$, Uschi Graham ${ }^{\mathrm{f}}$, D. Allan Butterfield" ${ }^{g}$ Eric A. Grulke ${ }^{\mathrm{h}}$, Robert A. Yokel ${ }^{\mathrm{i}}$

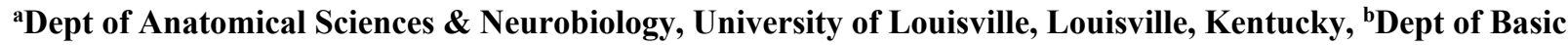
Medical Sciences, Guang Dong Pharmaceutical University, Guangzhou, Guangdong, 'Dept of Biology, University of Louisville, Louisville, Kentucky, 'Dept of Pathology and Laboratory Sciences,

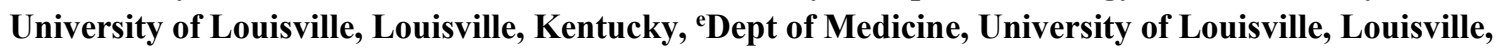
Kentucky, fCenter for Applied Energy Research, University of Kentucky, Lexington, Kentucky, ${ }^{\mathrm{g}}$ Dept of

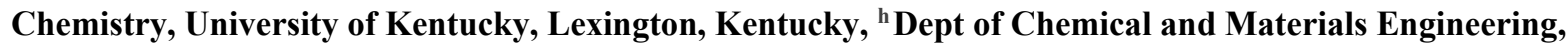
University of Kentucky, Lexington, Kentucky, ${ }^{i}$ Dept of Pharmaceutical Sciences, University of Kentucky, Lexington, Kentucky.

Michael T. Tseng, Ph.D., Department of Anatomical Sciences \& Neurobiology, University of Louisville, Louisville, Kentucky, Phone - 502-852-5170, Fax - 502-852-6228, email address - mttsen01@louisville.edu

Qiang Fu, M.D., Department of Basic Medical Sciences, Guang Dong Pharmaceutical University, Guangzhou, Guangdong, Phone - 502-852-5170, Fax - 502-852-6228, email address - FuQiang@GDPU.edu.cn

Khoua Lor, Department of Biology, University of Louisville, Louisville, Kentucky, Phone - 502-424-8651, Fax 502-852-0725, email address - k0lor001@louisville.edu

G Rafael Fernandez-Botron, Ph.D., Department of Pathology and Laboratory Sciences, University of Louisville, Louisville, Kentucky, Phone - 502-852-5375, email address - grfern01@louisville.edu

Zhong-Bin Deng, Ph.D., Department of Medicine, James Graham Brown Cancer Center, University of Louisville, Phone-502-852-8621, email address-z0deng01@louisville.edu

Uschi Graham, Ph.D., Center for Applied Energy Research, University of Kentucky, Lexington, Kentucky, Phone859-257-0299, email - graham@caer.uky.edu

D. Allan Butterfield, Ph.D., Department of Chemistry, Center of Membrane Sciences, University of Kentucky, Lexington, Kentucky 40506. Phone : 859-257-3184 ; email - dabcns@uky.edu

Eric Grulke, Ph.D. Department of Chemical \& Materials Engineering, University of Kentucky, Lexington, Kentucky, Phone-859-257-6097, email - eric.grulke@uky.edu

Robert Yokel, Ph.D., Department of Pharmaceutical Sciences, College of Pharmacy, University of Kentucky, Lexington, Kentucky, Phone: 859-257-4855, email: ryokel@email.uky.edu

Corresponding author: Michael T. Tseng, Ph.D., Department of Anatomical Sciences \& Neurobiology, School of Medicine, University of Louisville, 511 South Floyd Street, Room 212, MDR, Louisville, Kentucky 40202, Phone 502-852-5170, Fax - 502-852-6228, email address - mttsen01@louisville.edu 


\begin{abstract}
:
Understanding the long-term effects and possible toxicity of nanoceria, a widely utilized commercial metal oxide, is of particular importance as it is poised for development as a therapeutic agent based on its auto-catalytic redox behavior. We show here evidence of acute and subacute adverse hepatic responses, after a single infusion of an aqueous dispersion of $85 \mathrm{mg} / \mathrm{kg}, 30 \mathrm{~nm}$ nanoceria into Sprague Dawley rats. Light and electron microscopic evidence of avid uptake of nanoceria by Kupffer cells was detected in the liver as early as $1 \mathrm{~h}$ after infusion. Biopersistent nanoceria stimulated $\mathrm{CD}^{+}$lymphocyte proliferation that intermingled with nanoceria-containing Kupffer cells to form granulomata that were observed between days 30 and 90 . Ultrastructural tracking of ceria nanoparticles revealed [aggregated nanoceria in phagolysosomes. An increased formation of small nanoceria over time observed in the latter suggests possible dissolution and precipitation of nanoceria. However, the pathway for nanoceria metabolism/secretion remains unclear. Although frank hepatic necrosis was not observed, the retention of nanoceria increased hepatic apoptosis acutely, which persisted to day 90 . These findings, together with our earlier reports of $5 \mathrm{~nm}$ ceria-induced liver toxicity, provide additional guidance for nanoceria development as a therapeutic agent, and for its risk assessment.
\end{abstract}

Keywords: Electron microscopy, Immunohistochemistry, Histopathology, Liver, Risk identification 


\section{Introduction:}

Nanoscale materials are increasingly used in diagnostic imaging, for drug delivery, and in cosmetic formulations, but their toxic potential needs to be better understood. In vitro systems can inform, but do not substitute for whole animal studies. Concerns about potential toxicity from the use of nanomaterials have been expressed (Nel et al. 2006), and unusual rapid lung injury and extra-pulmonary toxicity among workers exposed to silica nanoparticles have been reported (Song and Tang 2011). Nanoceria, a widely used commercial metal oxide, is currently used as a fuel additive. This raises public concerns for potential, large-scale health impact. Cassee et al. (2011) recently reported ongoing exposure of a large human population to a new diesel emission containing ceria nanoparticles with an as yet unknown influence on public health. This report advocated more in vivo toxicological evaluation of characterized ceria nanoparticles to assess possible negative health impact. Towards that end, a recent study suggested dose-dependent hepatic toxicity after intratracheal instillation of nanoceria in the rat, and found that nanoceria translocated with ease from the lung to other organs. The liver is a major organ for biotransformation and a major site for nanomaterial clearance from blood and sequestration; and was the only organ that showed signs of injury (Nalabotu et al. 2011).

Nanoparticle size may also be an important determinant of potential toxicity. Nishimori et al. (2009) tested nano- and micro-sized silica particles $(70,300$, and $1000 \mathrm{~nm})$ as potential toxicants in mice, and reported that hepatic injury was only associated with $70 \mathrm{~nm}$ silica. Another study (Lankveld et al. 2010) indicated organ-specific and size-dependent accumulation of silver nanoparticles after intravenous (iv) administration in rats. Among the silver nanoparticles tested $(20,80$, and $110 \mathrm{~nm}), 20 \mathrm{~nm}$ particles exhibited higher affinity for the liver compared to

larger silver particles. Using the same size titanium dioxide particles, Xie et al. (2011) also reported liver and spleen accumulation that persisted in the rodent for up to 30 days.

Our group has been working to define potential toxic effects of nanoceria. We developed a single largedose vascular infusion model in rats and first reported acute systemic accumulation of nanoparticles with a relative lack of tissue injury using a commercially-prepared $30 \mathrm{~nm}$ ceria (Yokel et al. 2009). Subsequently, in-house synthesized extensively characterized nanoceria were used to examine acute and long-term responses to its infusion (Dan et al. 2012; Yokel et al. 2012). Focusing on liver, we reported biopersistence and hepatotoxicity 30 days after infusion of a $5 \mathrm{~nm}$ ceria in rats (Tseng et al. 2012). The same study revealed that nanoceria retention elicited systemic activation of T-cells, some of which intermingled with Kupffer cells in the liver sinusoid to form 
granulomata, a typical sign of chronic inflammatory response to materials that cannot be removed or cleared from cells and tissues.

Vascular clearance of polymeric nanosized particles can be influenced by tunable factors such as size, composition, and surface modification (Alexis et al. 2008). However, cellular uptake of metal and metal oxide nanoparticles does not ensure excretion Yang et al. 2007; Cho et al. 2009; Schipper et al. 2009). In the present study we aimed to further explore size-dependent nanoceria-induced biological effects in rodents using nanoceria cubes with an average particle size of $30 \mathrm{~nm}$. Our results showed a sustained increase in apoptotic cell number in the liver, and formation of liver granulomata 30 days after nanoceria infusion that persisted to 90 days. Ultrastructural analysis revealed nanoceria accumulations in Kupffer cells, stellate cells, and hepatocytes. The internalized nanoceria are mainly found in large phagolysosomes and in smaller lysosomes distributed near the cell perimeter. They did not penetrate organelles such as mitochondria and the nucleus. These findings, combined with our earlier reported results (Tseng et al. 2012; Yokel et al. 2009; Yokel et al. 2012), indicate that a single large vascular nanoceria infusion can result in prolonged systemic retention with hepatic injury.

\section{$2 \quad$ Methods:}

\subsection{Nanoceria synthesis and characterization:}

The approximately $30 \mathrm{~nm}$-sized ceria particles were synthesized under hydrothermal conditions (Mai et al. 2005) and prepared as an approximately 5\% aqueous citrate-stabilized ceria dispersion. The cerium content of the dispersion was determined by ICP-MS to accurately determine the nanoceria dose. Citrate coating (capping) was used to minimize agglomeration otherwise seen with uncoated ceria introduced into high ionic strength solutions, such as blood (Xia et al. 2008). A $20 \mathrm{ml}$ aqueous mixture of $1 \mathrm{mmol}$ cerium nitrate and 105 mmol sodium hydroxide was stirred for $0.5 \mathrm{~h}$. The resulting milky suspension was heated at $180^{\circ} \mathrm{C}$ for $24 \mathrm{~h}$ in a Teflon-lined stainless steel bomb. After washing with deionized water and ethanol the precipitate was dispersed in $0.05 \mathrm{M}$ citric acid aqueous solution with stirring overnight, followed by washing with water 5 times (Yokel et al. 2012). The resultant solution $(\mathrm{pH}=3.9)$ was sterilized before being infused into the rat.

A field emission analytical transmission electron microscope operated at 200-keV [JEOL JEM-2010F; Tokyo, Japan] was used for high resolution TEM (HRTEM). X-ray diffraction analysis (Siemens 5000 diffractometer) was used to determine crystallinity of the nanoceria. Particle size distribution was determined using dynamic light scattering (90Plus Nanoparticle Size Distribution Analyzer; Brookhaven Instruments Corp., 
Holtsville, NY). BET (Brunauer, Emmett, and Teller) analysis was used to measure the surface area of the dried ceria powder (Tristar 3000; Micromeritics Instrument Corp., Norcross, GA). Zeta potential, a measure of stability of the ceria dispersion, was determined in a Zetasizer ZS (Malvern Instruments, Worcestershire, U.K). Electron energy loss spectroscopy (EELS) which determines the relative ratio of Ce (III)/Ce (IV) by analyzing the $\mathrm{M}_{5} / \mathrm{M}_{4}$ ionization edges was performed with a JEOL $2010 \mathrm{~F}$ electron microscope. Images were acquired using the high resolution $(0.2$ $\mathrm{nm}$ ) probe. EELS spectra containing absorption edges specific to ceria were recorded using an alpha of $30 \mathrm{mrad}$, and a beta of 6 mrad. To minimize any possible electron beam interaction that could reduce cerium (IV) ions to the Ce (III) state, a less focused beam was used during the EELS analysis (Winterstein et al. 2008). The in situ bioaccumulated nanoceria was also characterized in Kupffer cells and hepatocytes by HRTEM as described in section 2.7. For the in situ nanoceria size distribution, nanoceria particles were measured from randomly chosen, digitized phagolysosome images taken from all study groups using NIS Elements software (BR 3.01, Nikon Instrument, Melville, NY).

\subsection{Animal care:}

Sixty adult male Sprague Dawley rats [weighing $316 \pm 27 \mathrm{~g}$ (mean $\pm \mathrm{SD}$ )] were housed individually in the University of Kentucky Division of Laboratory Animal Resources facility under a 12:12 h light: dark cycle at $70 \pm$ $8^{\circ} \mathrm{C}$ and 30 to $70 \%$ humidity. All rats had ad libitum access to 2018 Harlan diet and reverse osmosis water. Animal work was approved by the University of Kentucky Institutional Animal Care and Use Committee. The research was conducted in accordance with the Guiding Principles in the Use of Animals in Toxicology.

\subsection{Nanoscale ceria infusion:}

A cannula was surgically inserted, under sterile conditions, into each of the femoral veins and extended into the vena cava. The following day, un-anesthetized rats were iv infused via the shorter cannula with a ceria dispersion ( $85 \mathrm{mg}$ ceria/ $\mathrm{kg}$ ), or water (controls) adjusted to $\mathrm{pH} 3.9$ with citric acid, concurrently with an equal volume and rate of $1.8 \%$ saline infused into the second cannula to achieve net infusion of iso-isomotic solution. This approach was taken to avoid the extensive nanoceria agglomeration that results when it is dispersed in $0.9 \%$ sodium chloride or 10\% sucrose (Yokel et al. 2009). Each fluid was iv infused at rates of $2 \mathrm{ml} / \mathrm{kg} / \mathrm{h}$ over a duration of $1 \mathrm{~h}$.

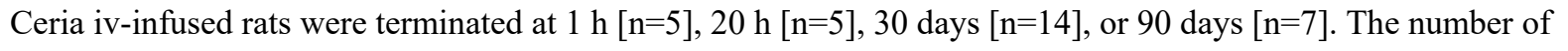


control rats was 5,8,10, and 6 respectively. The cannulae were surgically removed from the 30 and 90 day rats several days after the ceria or vehicle infusion. Respiratory, neurological, ophthalmic, gastrointestinal and other physiological statuses of the control and treated rats held for 30 and 90 days were assessed by daily cage-side observations. Rats assigned to day 30 and 90 groups were housed in metabolic cages from day 1 to day 14 after infusion to allow collection of urine and feces.

\subsection{Animal termination, tissue processing, and histopathology analysis:}

After termination of ketamine/xylazine-anesthetized rats, blood was obtained from which serum was collected, aliquoted, and stored frozen. Nine organs were excised and weighed. Tissues were harvested from the liver (tip of the right middle lobe), lung, kidney, spleen, heart, thymus, and brain and were fixed in $10 \%$ neutral buffered formalin and processed for histopathology analysis. Sections $(5 \mu \mathrm{m})$, stained with hematoxylin and eosin were examined for qualitative and quantitative changes. Nanoceria-containing Kupffer cells were detected by their enlarged size and sinusoidal location; their density determined and expressed as number per $\mathrm{mm}^{2}$. Hepatic granulomata were digitally recorded and their size measured with Neurolucida software (MBF Bioscience, Williston, VT) in a Nikon Eclipse E-800 microscope, to tabulate their density. The lesions were assessed on coded slides by an observer unaware of the experimental setting.

\subsection{Immunohistochemistry (IHC):}

The presence of T-cells in liver parenchyma was determined by IHC using anti-CD3 rabbit monoclonal antibody (clone SP7, Spring Bioscience, Pleasanton, CA). Briefly, $5 \mu \mathrm{m}$ sections were deparaffinized, boiled in hot citrate buffer for antigen retrieval, and incubated with anti-CD3 antibody [1:100] for $60 \mathrm{~min}$ at room temperature. Immunoreactive complexes were detected using the avidin-biotin affinity system (Dako North America, Carpinteria, CA), and visualized with 3, 3'-diaminobenzidine tetrahydrochloride (Zymed Laboratories, San Francisco, CA) as a substrate. The sections were counterstained with Mayer's hematoxylin and mounted with a cover slip. Controls included substitution of primary antibody with phosphate buffered saline and human thymus tissue as a positive tissue control.

Nanoceria-induced cellular degeneration and proliferation in liver tissue were determined by TUNEL and proliferating cell nuclear antigen (PCNA) immunostaining, respectively. Deparaffinized slides were prepared for 
TUNEL assay according to the protocol supplied with the ApopTag Plus Peroxidase In Situ Apoptosis Detection Kit (S7101) (Millipore, Billerica, MA) with positive reaction control using DNase treatment, negative reaction control created by deleting the TdT enzyme, and positive tissue control with active apoptotic components as supplied by the manufacturer. Additionally apoptosis was evaluated by immunofluorescence labeling of caspase 3. Deparaffinized liver sections were hydrated and blocked for $60 \mathrm{~min}$ at $25^{\circ} \mathrm{C}$ with $5 \% \mathrm{BSA}$ in PBS, and incubated overnight at $\underline{4}^{\circ} \mathrm{C}$ with anti-caspase 3 antibody (1:100, Oncogene research products) in PBS. Primary antibody was detected with Alexa Fluor 488 conjugated goat anti-mouse $\operatorname{IgG}(1: 600$, Invitrogen Life Sciences). Tissues were counterstained with DAPI and images were captured on a Zeiss LSM 510 confocal microscope equipped with a digital image analysis system (Pixera).

PCNA immunohistochemistry, which detects nuclear antigen synthesized in early G1 and S phases of the cell cycle, was used to assay for possible nanoceria-induced cellular proliferation. After antigen retrieval, endogenous peroxidase activity was quenched with a $3 \%$ hydrogen peroxide solution, and nonspecific binding blocked with IgG-free bovine serum albumin (Jackson ImmunoResearch Laboratories, West Grove, PA), before staining overnight at $4^{\circ} \mathrm{C}$ using a monoclonal anti-PCNA antibody (SC-56, Millipore, Billerica, MA) at a dilution of 1:300. Subsequently, the signal was visualized using a secondary anti-mouse antibody at 1:500 dilution (\#AP308P, Millipore, Billerica, MA) and the ImmPACT DAB kit (SK-4105, Vector Labs, Burlingame, CA). Controls included substitution of primary antibody with phosphate buffered saline and human melanoma tissue as a positive tissue control.

\subsection{Serum Biochemistry:}

To assess possible hepatotoxicity serum alanine aminotransferase (ALT) was measured using a commercial spectrophotometric diagnostic kit (Thermo Scientific). Briefly, blood samples were centrifuged at $1,000 \times \mathrm{g}$ for 10 min within $1 \mathrm{~h}$ after collection to generate serum which was stored at $-80^{\circ} \mathrm{C}$. Serum ALT was measured using a kinetic UV method based on the oxidation of NADH to NAD and corresponding decrease in OD at a wavelength of $340 \mathrm{~nm}$ read in a Biotek Synergy HT Plate reader (MTX Lab Systems, Inc., Vienna, Virginia,), and the results expressed as U/L. Reagents for ALT were purchased from Thermo Scientific 


\subsection{Electron microscopy of ceria in liver:}

Immediately after excision, thin strips of liver samples were cut and immersion fixed in $10 \%$ neutral buffered formalin for $24 \mathrm{~h}$ before dissection into $3 \mathrm{~mm}^{3}$ pieces, post fixed in $2 \%$ aqueous osmium tetraoxide, dehydrated in ascending concentrations of ethanol, and embedded in Araldite 502. One micron thick sections were made, stained with toluidine blue for light microscopy observation and screening. Selected blocks were sectioned at $800 \AA$, mounted on 200-mesh copper grids, and examined in a Phillips CM-10 electron microscope equipped with $\mathrm{LaB}_{6}$ cathode (Phillips Electronic Instruments Co. Eindhoven, The Netherlands) operated at $80 \mathrm{kV}$. For high resolution microscopy, sections were collected on Formvar/carbon coated copper grids (200-mesh, Ted Pella Inc. Redding, CA), without staining, for TEM/STEM/EELS analysis (JEOL 2010 operated at $200 \mathrm{kV}$ ).

\subsection{Data analysis and statistics:}

For cell proliferation, degeneration analysis, and $\mathrm{CD}^{+} \mathrm{IHC}$ results were statistically analyzed using Student's t-test. Comparison between groups was analyzed by the one-tailed Student's t-test (SPSS, Chicago, Ill, USA). Differences were considered to be statistically significant when the P values were less than 0.05 .

\section{Results:}

\subsection{General observations of the ceria-infused rats:}

No mortality was observed after nanoceria infusion over the duration of the experiment. The treated rats showed a reduced body weight gain compared with controls during the first week after ceria infusion. Splenomegaly was consistently observed in ceria-infused rats at necropsy, with no gross abnormality in major organs including liver and lung.

\subsection{Characterization of the nanoceria:}

The as-synthesized ceria nanoparticles (Figure 1a) were well-crystallized cubes with defined crystal faces (100). Only a few crystals exhibited (111) faces. The particle size range, as determined by HR-TEM, was approximately $5-100 \mathrm{~nm}$ with the majority between 20 and $50 \mathrm{~nm}$ (Figure 1b).

In situ localization of nanoceria showed a preponderance of nanoparticle accumulation in phagolysosomes (Figure 1c). A highly disperse size distribution was observed in phagolysosomes of Kupffer cells. A total of 19,229 nanoceria particles from 55 phagolysosomes were measured and used to calculate a monomodal continuous distribution at each time point studied. The in situ nanoceria cubes show a shift towards smaller-sized particles over 
the 90 day period. While nearly $50 \%$ of all the particles sized were less than $30 \mathrm{~nm}$ in the as-synthesized ceria, the size distribution shifted toward a decreased particle size with less than $\approx 10 \mathrm{~nm}$ particles accounting for nearly $50 \%$ of the particles counted (Figure 1d).

\subsection{Ceria-induced histological changes in the liver:}

The general histological features of the hepatocellular cords in the liver were not altered by nanoceria administration at all time points measured. As early as $1 \mathrm{~h}$ post infusion, ceria internalization in Kupffer cells was observed. The captured ceria caused cellular enlargement and bulging of the Kupffer cell surface, observable in H \& E stained sections. Toluidine blue-stained $1 \mu \mathrm{m}$ plastic sections offered exceptionally detailed views of the Kupffer cells punctuated with brownish ceria aggregates, as shown in Figure 2. The adjacent hepatocytes appeared normal and contained a full complement of cytoplasmic organelles (Figure 2A-2D). Granulomata were observed in the 30 and 90 day nanoceria-treated rats (Figure 2C, 2D) and appeared to co-exist with the hepatocytes without imparting hepatocyte injury. The number of nanoceria-containing Kupffer cells dispersed throughout the liver parenchyma rose quickly in the first hour after ceria infusion from 0 in control rats to $30.8 \pm 2.5$ cells $/ \mathrm{mm}^{2}$, but declined by $20 \mathrm{~h}$ $\left(11.8 \pm 1.2\right.$ cells $\left./ \mathrm{mm}^{2}\right)$ and remained steady at 30 days $\left(14.0 \pm 3.0 \mathrm{cells} / \mathrm{mm}^{2}\right)$, before increasing again at 90 days $\left(36.5 \pm 5.7\right.$ cells $\left./ \mathrm{mm}^{2}\right)$. Statistical difference was found between all paired groups, except for between $20 \mathrm{~h}$ and 30 day rats. Adjacent to the sinusoidal space, occasional hepatic stellate cells exhibiting hyperchromatic nuclei with occasional lipid inclusions were observed. The hepatocellular cords surrounding the sinusoidal space showed only occasional and low level nanoceria storage 1 or $20 \mathrm{~h}$ post infusion. Over time, the nanoceria-laden Kupffer cells intermingled with mononucleated cells in the sinusoids to form granulomata. This was a distinct feature of the hepatic tissue 30 and 90 days after only the single nanoceria treatment. The observed granulomata were of nonnecrotizing type with nanoceria accumulation in the phagocytes. The average size of the granulomata measured $1,206 \pm 374$ and 1,654 $\pm 835 \mu \mathrm{m}^{2}$ for days 30 and 90, respectively. In spite of the slight increase in granuloma size, their number expressed per $100 \mathrm{~mm}^{2}$ remained stable $\left(1.42 \pm 1.16\right.$ and $\left.1.42 \pm 0.75 / \mathrm{mm}^{2}\right)$.

Immunohistochemistry revealed the presence of $\mathrm{CD}^{+} \mathrm{T}$-cells in the granulomata (Figure 3A). In addition, collagen fiber bundles stained by Masson Trichrome were observed in the periphery of granulomata and in perivascular spaces (Figure 3B) without signs of generalized, diffuse fibrosis. The average number of $\mathrm{CD}^{+}$labeled cells per granuloma for 30 and 90 day rats was $2.4 \pm 1.6$ and $3.9 \pm 1.7$, respectively. The numbers of $\mathrm{CD}^{+}$cells in 
liver tissue parenchyma of nanoceria-infused rats increased from $4.6 \pm 1.8$ cells $/ \mathrm{mm}^{2}$ at $1 \mathrm{~h}$, to $32.8 \pm 18.9 \mathrm{cells} / \mathrm{mm}^{2}$ by day 90 (Figure 4).

\subsection{Ceria-induced hepatic ultrastructure changes:}

Hepatic ultrastructural changes were examined in detail using electron microscopy. Nanoceria particles were only occasionally observed in the sinusoidal lumen at the time points measured. The majority of the electrondense nanoceria continued to appear in Kupffer cell cytoplasm throughout the time points studied. The internalized nanoceria appeared as aggregatesof varying dimensions and were mostly enclosed by the cell membrane (Figure 5A). The size of the nanoparticles ranged from a few nanometers, to cubes exceeding $200 \mathrm{~nm}$ (Figure 5B, 5C). Once internalized, ceria aggregates underwent fusion with lysosomes to form phagolysosomes. Against the amorphous matrix background, a range of spherical to oblong shaped proteinaceous inclusions and membrane fragments also appeared in the phagolysosomes (Figure 5D). While many of these large spherical cytoplasmic inclusions were situated near the cell surface, direct fusion with the plasma membrane leading to nanoceria discharge was not observed. Nanoceria penetration into organelles including the nucleus was not observed.

Within the hepatocellular cords the lining endothelial cells and perivascular stellate cells showed occasional ceria uptake (Figure 6A, 6B). Stellate cells with their fusiform shape, smaller cell volume, and occasional lipid droplets can be distinguished from other cellular components. Figures 6B illustrate these features in stellate cells taken on days 30 and 90. Little nanoceria uptake and retention was observed in hepatocytes. However, occasional solitary ceria inclusions, containing highly compacted crystalline particles, reaching $5 \mu \mathrm{m}$ in diameter, were observed in hepatocytes (Figure 6C). The surrounding endoplasmic reticulum arrays, mitochondria, and the cell nucleus of these hepatocytes appeared normal and unaffected. Toward the cell periphery, many hepatocytes displayed numerous spherical lysosomal bodies. The interior of these bodies contained spherical electron-opaque droplets with occasional cube-like materials. However, active discharge of electron-dense material into the bile canaliculi was not observed, and the bile duct lining cells in the periportal region were devoid of ceria-like inclusion (Figure 6D).

Granulomata found at days 30 and 90 were formed by a mixture of ceria-laden Kupffer cells and a few nonceria accumulating mononuclear cells (Figure 7A, 7B). Phagocytic cells in the granuloma enclosed an array of different nanoceria crystal sizes as illustrated by TEM and STEM images (Figure 7C, $7 \mathrm{C}_{1}$ ). Numerous EELS 
analyses performed on the these nanoparticles demonstrated that the nanoceria crystal's outer surface, or face, stays (from freshly made to 90 days) always enriched in Ce (III) as compared with the bulk (core) of the nanoparticles which are stoichiometric $\mathrm{CeO}_{2}$ with an approximately equal amount of $\mathrm{Ce}$ (III) and $\mathrm{Ce}$ (IV). Figure 7D shows the enrichment of Ce (III) at the outermost surface of an internalized nanoceria particle which was demonstrated by the ratios of the $\mathrm{M}_{4}$ and $\mathrm{M}_{5}$ peak intensities for $\mathrm{Ce}$ in the corresponding EELS spectrum.

\subsection{Ceria-induced hepatic cell turnover:}

Acute presence of nanoceria caused a statistically significant increase in the number of apoptotic cells by $20 \mathrm{~h}$ that was sustained to 30 and 90 days after infusion (Figure 8A). The sustained increase of apoptotic cell in the subacute groups was confirmed by caspase 3 immunohistochemistry (Figure 9). Concurrently, cell proliferation analysis as indicated by PCNA staining showed a similar trend, although the number of G1/S phase positively stained cells was not statistically significantly different from controls until 90 days, when there was a robust and statistically significant elevation in proliferating cells (Figure 8B).

\subsection{Ceria-induced alteration in serum biochemical profile:}

Hepatic ALT level was assayed as an index of hepatic injury in response to $30 \mathrm{~nm}$ ceria infusion. Consistent with the histological data, serum ALT levels were mildly elevated, reaching a peak of $30.33 \pm 16.08 \mathrm{U} / \mathrm{L}$ by $20 \mathrm{~h}$ (control level was $20.71 \pm 15.39 \mathrm{U} / \mathrm{L}$ ) and subsequently declined over time reaching a nadir on day 90 in ceria-infused rats (Figure 10). Although ALT levels in the nanoceria-treated animals were consistently higher than in controls, the differences were not statistically significant.

\section{Discussion:}

In-depth morphological probing showed that rats tolerated a single large dose nanoceria infusion without mortality, as previously reported (Tseng et al. 2012; Yokel et al. 2012). The small decrease of cerium in the sampled sites to 90 days is consistent with the less than $1 \%$ nanoceria excretion in urine and feces in the first 2 weeks after nanoceria infusion (Yokel et al. 2012) and lack of nanoceria in the bile ducts (Figure 6). Avid Kupffer cell uptake of nanoceria was observable as early as $1 \mathrm{~h}$ by light microscopy. Such uptake is similar to that reported after fluorescently-labeled mesoporous silica in mice (Cheng et al. 2012). Persistent particles and non-degradable antigens are known to induce a T-cell-mediated delayed hypersensitivity reaction leading to granuloma formation 
(Kumar et al. 2007). Similar to our previous report with $5 \mathrm{~nm}$ ceria, the hepatic granulomata were a consistent hepatic cytological feature on days 30 and 90 after a single infusion of nanoceria.

Although the size of the ceria-induced granulomata were small, and were of non-necrotizing type, the basic component of Kupffer cell aggregate surrounded by T-lymphocytes as reported in other granulomata was preserved (Ulrichs and Kaufmann 2006). Single and repeated iv infusion of $20-80 \mathrm{mg} / \mathrm{kg}$ hollow silica nanoparticles in mice produced similar findings of lymphocytic infiltration, hepatocyte microgranulation, as well as the accumulation of nanoparticles in the macrophage (Liu et al. 2011). Intraperitoneal injection of the same silica nanoparticle also produced hepatic granulomata (Liu et al. 2012). A study in bacillus Calmette-Guerin (BCG)-infected mice reported CD11c+ inflammatory dendritic cells migrated in and out of the granulomata to prime T-cells (Schreiber et al. 2011). Akin to the bacteria-induced granuloma where persistent residual bacterial presence provides the immune stimulant, it is possible that persistent nanoceria causes similar shuffling of dendritic cells to induce the observed T-cell activation. Glucan-induced granuloma formation in mice showed self-renewing Kupffer cells contributed to the observed pathology (Yamada et al. 1990; Co et al. 2004). Nanoceria-induced T-cell migration in this and other nanoparticle models suggests a trend of induced host immunological responses to internalized nanoparticles. A knowledge of pathways involved in metabolism or excretion of nanoparticles is central to our understanding of nanoceria retention. How the body resolves granulomata and inflammatory responses induced by nanoceria retention needs to be understood before nanoceria can be deployed as a therapeutic agent.

Our nanoceria in spite of its multivalent state, continued to retain a surface-to-core valence gradient, with an enrichment of Ce (III) at the surface, in ceria retained cells over the 90 day observation period. A recent study indicated crystalline defects may be associated with increased silver ion release and higher toxicity in a rainbow trout gill epithelial cell line, RT-W1 (George et al. 2012). Exposing cells from the human monomyelocytic leukemia cell line, THP-1, to high aspect ratio ceria nanorods caused cytotoxicity and increased IL-1 $\beta$ production (Ji et al. 2012). shorter internalized ceria nanorods were clustered in phagolysosomes whereas the longer self-adhering $\mathrm{CeO}_{2}$ nanowires, at times, pierced the cell membrane resulting in nanoceria release. Although some phagolysosomes were found near the cell membrane, piercing of the plasmalemma with concomitant discharge of ceria nanocubes was not observed in our study, consistent with prolonged nanoceria processing within phagolysosomes. Perhaps 
nanoceria in the presence of highly acidic lysosomal fluid is digested, releasing the metal ion to form new ultrafine nanoceria as well as the larger crystal by the Oswald ripening effect. The appearance of very fine and larger nanocrystals suggests a critical role of the phagolysosome in the metabolism of nanoceria. While the mechanisms remain to be elucidated, the clinical presentation of metal fume fever appeared to be associated with lysosomal dissolution/releasing of $\mathrm{ZnO}$ nanoparticles (Kuschner et al. 1995; [not a relevant reference. Not about $\mathrm{Zn}$ or metal fune fever] Taira et al. 2010), localized release of $\mathrm{Ni}$ from a presumed insoluble compound playing a role in tumor formation (Pott et al. 1992), and lysosomal-induced release of nickel ions with nuclear translocation in respiratory epithelial cells, all point to the pivotal role of the phagolysosome in nanoparticle metabolism and elimination (Goodman et al. 2011). Other reports on lysosomal instability, phagolysosomal membrane breakage, and appearance of finer nanoparticles (Cho et al. 2011; Miyawaki et al. 2009; Rossi et al. 2009; Taira et al. 2010; Tsai et al. 2012) further indicate that the stability of the nanoparticle after phagolysosome enclosure is a major determinant of cellular toxicity.

Absence of necrotic areas and a lack of fibrosis in the liver suggest that the continuous presence of nanoceria may be tolerated by the host. The rapid elevation in ALT is consistent with an initial acute, although mild, liver injury. The slow return of ALT to the baseline by day 90 suggests a functional stabilization of injury in the liver after nanoceria infusion. In addition to the capacity to take up nanoparticles, Kupffer cells (Lenaerts et al. 1984, Sadauskas et al. 2007) may have a dual role secreting hepatoprotective interleukin-6, as well as TNF- $\alpha$ (Gao 2012). Granulomatous formation is known to be associated with chronic inflammation, thus, the source of subacute or chronic inflammatory stimulation needs to be ascertained. Against the trend of functional stabilization over time including a lack of frank necrosis or diffuse fibrosis, hepatocellular turnover, as revealed by TUNEL assay, caspase $3 \mathrm{IHC}$, and PCNA staining, raises some concern. Increased cellular proliferation in parallel with increased apoptosis raises the possibility that nanoceria could alter the liver cytoarchitecture over longer survival time.

We have shown a time-dependent increase in $\mathrm{CD}^{+} \mathrm{T}$-lymphocyte populations (Figure 4) and like other macrophages, Kupffer cells can be replenished under stress conditions through local proliferation as well as by a blood-borne pathway from the bone marrow (Wisse 1974; Bouwens et al. 1984; Naito et al. 1997). Besides the high content of ceria in liver, it is important to note that other tissues including the bone marrow retained considerable ceria (Yokel et al. 2012). The population kinetics of Kupffer cells and T cells may be central to the 
understanding of nanoceria biopersistence in liver; other tissue with large ceria retention including the bone marrow will be included in future investigations.

\section{Conclusion:}

The current study investigated the effect of a single infusion of nanoceria cubes both acutely and over a longer observation period, to further test our hypothesis that nanoceria imparts a relatively mild but persistent hepatic inflammatory response. The rapid capturing of larger nanoceria cubes by Kupffer cells and its ease of tracking by light microscopy should allow for easier evaluation of this cell subpopulation for future studies using cubic shaped metal oxide nanoparticle. At the ultrastructural level, our data indicate that internalized nanoceria particles were associated with phagolysosomes without organelle penetration including mitochondria and the nucleus, and those nanoparticles were not discharged into the biliary system. Further, Kupffer cells laden with nanoceria may play a pivotal role in the stimulation of other immune cells, such as T-cells, causing increased cell turnover (i.e. increased apoptosis), and the formation of granulomata. Greater understanding of the role of the Kupffer cell in metabolic processing, inflammatory modulation, and immunological responses toward this rareearth nanoparticle is needed. Knowledge gained should influence the design of nanotechnology-based therapeutic delivery systems to treat a variety of diseases, including those of the liver.

\section{Declaration of Interest}

The authors report no conflict of interest and they alone are responsible for the content and writing of the paper. This work was supported by United States Environmental Protection Agency Science to Achieve Results [grant number RD-833772]. Although the research described in this article has been funded wholly or in part by the United States Environmental Protection Agency through STAR Grant RD-833772, it has not been subjected to the Agency's required peer and policy review and therefore does not necessarily reflect the views of the Agency and no official endorsement should be inferred.

\section{Reference:}

Alexis F, Pridgen E, Molnar LK, Farokhzad OC., (2008) Factors affecting the clearance and biodistribution of polymeric nanoparticles. Mol Pharm. 5,505-15. 
Bouwens L, Baekeland M, Wisse E., (1984) Importance of local proliferation in the expanding Kupffer cell population of rat liver after zymosan stimulation and partial hepatectomy. Hepatology. 4,213-9.

Cassee FR, van Balen EC, Singh C, Green D, Muijser H, Weinstein J, Dreher K., (2011) Exposure, health and ecological effects review of engineered nanoscale cerium and cerium oxide associated with its use as a fuel additive. Critical Reviews in Toxicology. 41,213-29.

Cheng SH, Li FC, Souris JS, Yang CS, Tseng FG, Lee HS, Chen CT, Dong CY, Lo LW., (2012) Visualizing dynamics of sub-hepatic distribution of nanoparticles using intravital multiphoton fluorescence microscopy. ACS Nano. $22,4122-31$

Cho WS, Cho M, Jeong J, Choi M, Cho HY, Han BS, Kim SH, Kim HO, Lim YT, Chung BH, Jeong J., (2009) Acute toxicity and pharmacokinetics of $13 \mathrm{~nm}$-sized PEG-coated gold nanoparticles. Toxicol Appl Pharmacol. 236,16-24.

Cho WS, Duffin R, Howie SE, Scotton CJ, Wallace WA, MacNee W, Bradley M, Megson IL, Donaldson K., (2011) Progressive severe lung injury by zinc oxide nanoparticles; the role of $\mathrm{Zn}^{2+}$ dissolution inside lysosomes, Particle \& Fibre Toxicolgy. 8,27.

Co DO, Hogan LH, Kim SI, Sandor M., (2004) Mycobacterial granulomas: keys to a long-lasting host-pathogen relationship, Clin Immunol. 113,130-6.

Dan M, Wu P, Grulke EA, Graham UM, Unrine JM, Yokel RA., (2012) Ceria-engineered nanomaterial distribution in, and clearance from, blood: size matters. Nanomedicine (Lond).7,95-110.

Gao B., (2012) Hepatoprotective and anti-inflammatory cytokines in alcoholic liver disease. J Gastroenterol Hepatol. 2 (27 Suppl),89-93.

George S, Lin S, Ji Z, Thomas CR, Li L, Mecklenburg M, Meng H, Wang X, Zhang H, Xia T, Hohman JN, Lin S, Zink JI, Weiss PS, Nel AE., (2012) Surface defects on plate-shaped silver nanoparticles contribute to its hazard potential in a fish gill cell line and zebrafish embryos. ACS Nano.6,3745-59.

Goodman JE, Prueitt RL, Thakali S, Oller AR., (2011) The nickel ion bioavailability model of the carcinogenic potential of nickel-containing substances in the lung. Critical Reviews in Toxicology. 41,142-74.

Ji Z, Wang X, Zhang H, Lin S, Meng H, Sun B, George S, Xia T, Nel AE, Zink JI, (2012) Designed synthesis of $\mathrm{CeO}_{2}$ nanorods and nanowires for studying toxicological effects of high aspect ratio nanomaterials. ACS Nano 6(6):5388-80.

Kumar V, Abbas A, Fausto N, Mitchell R. (2007) In: Kumar V, Abbas A, Fausto N, Mitchell R. (eds) Robbins Basic Pathology, Eighth Edition.: Saunders, Elsevier; Philadelphia, p. 56-7.

Kuschner WG, D'Alessandro A, Wintermeyer SF, Wong H, Boushey HA, Blanc PD., (1995) Pulmonary responses to purified zinc oxide fume. J Investig Med. 43:371-8.

Lankveld DP, Oomen AG, Krystek P, Neigh A, Troost-de Jong A, Noorlander CW, Van Eijkeren JC, Geertsma RE, De Jong WH., (2010) The kinetics of the tissue distribution of silver nanoparticles of different sizes.

Biomaterials.31:8350-61.

Lenaerts V, Nagelkerke JF, Van Berkel TJ, Couvreur P, Grislain L, Roland M, Speiser P., (1984) In vivo uptake of polyisobutyl cyanoacrylate nanoparticles by rat liver Kupffer, endothelial, and parenchymal cells. J Pharm

Sci.73:980-2. 
Liu T, Li L, Teng X, Huang X, Liu H, Chen D, Ren J, He J, Tang F., (2011) Single and repeated dose toxicity of mesoporous hollow silica nanoparticles in intravenously exposed mice. Biomaterials.32:1657-68.

Liu T, Li L, Fu C, Liu H, Chen D, Tang F., (2012) Pathological mechanisms of liver injury caused by continuous intraperitoneal injection of silica nanoparticles. Biomaterials.33:2399-407.

Mai HX, Sun LD, Zhang YW, Si R, Feng W, Zhang HP,Liu HC, Yan CH., (2005) Shape-selective synthesis and oxygen storage behavior of ceria nanopolyhedra, nanorods, and nanocubes. The Journal of Physical Chemistry B.109:24380-5.

Miyawaki J, Matsumura S, Yuge R, Murakami T, Sato S, Tomida A, Tsuruo T, Ischihashi T, Fujinami T, Irie H, Tsuchida K, Lijima S, Shiba K, Yudasaka M., (2009) Biodistribution and ultrastrucutral localization of single-walled carbon nanohorns determined in vivo with embedded $\mathrm{Gd}_{2} \mathrm{O}_{3}$ labels, ACS Nano 3:1399-1406.

Naito M, Hasegawa G, Takahashi K., (1997) Development, differentiation, and maturation of Kupffer cells. Microsc Res Tech.39:350-64.

Nalabotu SK, Kolli MB, Triest WE, Ma JY, Manne ND, Katta A, Addagarla HS, Rice KM, Blough ER., (2011) Intratracheal instillation of cerium oxide nanoparticles induces hepatic toxicity in male Sprague-Dawley rats. International Journal of Nanomedicine.6:2327-35.

Nel A, Xia T, Madler L, Li N., (2006) Toxic potential of materials at the nanolevel. Science.311:622-7.

Nishimori H, Kondoh M, Isoda K, Tsunoda S, Tsutsumi Y, Yagi K., (2009) Silica nanoparticles as hepatotoxicants. Eur J Pharm Biopharm. 72:496-501.

Pott F, Rippe R, Roller M, Csicsaky M, Rosenbruch M, Huth F. Carcinogenicity of nickel compounds and nickel alloys in rats by i.p. injection., (1992) In: Nieboer E, Nriague J, editors. Nickel and human health: current perspectives. New York: John Wiley and Sons, pp. 491-502.

Rossi EM, Pylkkänen L, Koivisto AJ, Vippola M, Jensen KA, Miettinen M, Sirola K, Nykäsenoja H, Karisola P, Stjernvall T, Vanhala E, Kiilunen M, Pasanen P, Mäkinen M, Hämeri K, Joutsensaari J, Tumoi T, Jokiniemi J, Wolff H, Savolainen K, Matikainen S, Alenius H., 2010, Airway exposure to silica-coated $\mathrm{TiO}_{2}$ nanoparticles induces pulmonary neutrophilia in mice, Toxicol Sci. 113:422-433.

Sadauskas E, Wallin H, Stoltenberg M, Vogel U, Doering P, Larsen A, Danscher G., (2007) Kupffer cells are central in the removal of nanoparticles from the organism. Particle and Fibre Toxicology.4:10.

Schipper ML, Iyer G, Koh AL, Cheng Z, Ebenstein Y, Aharoni A, Keren S, Bentolila LA, Li J, Rao J, Chen X, Banin U, Wu AM, Sinclair R, Weiss S, Gambhir SS., (2009) Particle size, surface coating, and PEGylation influence the biodistribution of quantum dots in living mice. Small.5:126-34.

Schreiber HA, Harding JS, Hunt O, Altamirano CJ, Hulseberg PD, Stewart D, Fabry Z, Sandor M., (2011) Inflammatory dendritic cells migrate in and out of transplanted chronic mycobacterial granulomas in mice. J Clin Invest.121:3902-13.

Song Y, Tang S., (2011) Nanoexposure, unusual diseases, and new health and safety concerns. TheScientificWorldJournal.11:1821-8.

Taira M, Kagiya T, Harada H, Sasaki M, Kimura S, Narushima T, Nezu T, Araki Y., (2010) Microscopic observation and inflammatory cytokine productions of human macrophage phagocytising submicron titaniun particles, J Mater Sci Mater Med. 21:267-275. 
Tsai CY, Lu SI, Hu CW, Yeh CS, Lee GB, Lei HY., (2012) Size-dependent attenuation of TLR9 signaling by gold nanoparticles in macrophages, J Immunol. 188:68-76.

Tseng MT, Lu X, Duan X, Hardas SS, Sultana R, Wu P, Unrine JM, Graham U, Butterfield DA, Grulke EA, Yokel RA., (2012) Alteration of hepatic structure and oxidative stress induced by intravenous nanoceria. Toxicol Appl Pharmacol.260:173-82.

Ulrichs T, Kaufmann SHE., (2006) New insights into the function of granulomas in human tuberculosis., The Journal of Pathology.208:261-9.

Winterstein JP, Basu J, Herzing A, Anderson IM., Carter C., (2008) Combined structural and chemical investigations of ceria nanoparticles in the TEM. Microscopy and Microanalysis.14:280-1.

Wisse E., (1974) Kupffer cell reactions in rat liver under various conditions as observed in the electron microscope. Journal of Ultrastructure Research. 46:499-520.

Xia T, Kovochich M, Liong M, Mädler L, Gilbert B, Shi H,Yeh JI, Zink JI, Nel AE., (2008) Comparison of the mechanism of toxicity of zinc oxide and cerium oxide nanoparticles based on dissolution and oxidative stress properties. ACS Nano.2:2121-34.

Xie G, Wang C, Sun J, Zhong G., (2011) Tissue distribution and excretion of intravenously administered titanium dioxide nanoparticles. Toxicol Lett.205:55-61.

Yamada M, Naito M, Takahashi K., (1990) Kupffer cell proliferation and glucan-induced granuloma formation in mice depleted of blood monocytes by strontium-89. J Leukoc Biol.47:195-205.

Yang ST, Guo W, Lin Y, Deng XY, Wang HF, Sun HF, Liu YF, Wang X, Wang W, Chen M, Huang YP, Sun YP., (2007) Biodistribution of pristine single-walled carbon nanotubes in vivo. J.Phys. Chem C.111:17761-4.

Yokel RA, Florence RL, Unrine JM, Tseng MT, Graham UM, Wu P, Grulke, E.A., Sultana, R., Hardas, S.S., Butterfield, D.A., (2009) Biodistribution and oxidative stress effects of a systemically-introduced commercial ceria engineered nanomaterial. Nanotoxicology.3:234-48.

Yokel RA, Au TC, MacPhail R, Hardas SS, Butterfield DA, Sultana R, Goodman M, Tseng MT, Dan M, Haghnazar H, Unrine JM, Graham UM, Wu P, Grulke EA., (2012) Distribution, elimination, and biopersistence to 90 days of a systemically introduced $30 \mathrm{~nm}$ ceria-engineered nanomaterial in rats. Toxicol Sci.127:256-68. 


\section{Figure legends}

Figure 1: High-resolution transmission electron microscopy image of as-synthesized nanoceria cubes with welldefined faces (A) and size distribution (B). The in situ retention of nanoceria in a phagolysosome (C) and an in situ cumulative particle distribution curve is plotted from particle sizes grouped from 0 to $10 \mathrm{~nm}, 25$ to $35 \mathrm{~nm}, 50$ to 60 $\mathrm{nm}, 75$ to $85 \mathrm{~nm}$, and $100+\mathrm{nm}(\mathrm{D})$.

Figure 2: Time-dependent histological features of nanoceria infusion in liver parenchyma. Toluidine blue stained sections of liver from nanoceria-infused rats after $1 \mathrm{~h}$ (A), $20 \mathrm{~h}$ (B), 30 days (C), and 90 days (D). Arrows point to ceria-laden Kupffer cells in earlier time points and inside of granulomata formation at later time points.

Figure 3: (A) Immunohistochemical staining of $\mathrm{CD}^{+}$cells (arrow) in liver 30 days after ceria infusion. In this granuloma a Kupffer cell is indicated by an asterisk. (B) Masson Trichrome staining indicating collagen fiber bundles (arrow) formed at the periphery of a granuloma and in the liver parenchyma.

Figure 4: Increased $\mathrm{CD}^{+} \mathrm{T}$-cell number in hepatic parenchyma of nanoceria-infused rats over time. Number of CD $3^{+}$ T-cells per $\mathrm{mm}^{2}$ of liver tissue as imaged by light microscopy of immunohistochemical-stained liver tissue from $1 \mathrm{~h}$ to 90 days after either control or nanoceria infusion. Statistical difference by two-tailed T test between treated and control pair is indicated by an asterisk.

Figure 5: Transmission electron microscopy images of Kupffer cells in liver sections from rats at $1 \mathrm{~h} \mathrm{(A),} 20 \mathrm{~h}$ (B), 30 days (C) and 90 days (D) after nanoceria infusion. Arrows indicate electron dense nanoceria particles of varyingsized aggregates. Details of a phagolysosome with fluid interior, membrane fragments (small arrow), proteinaceous inclusions (circle), and dotting nanoceria particles are shown (D). $\mathrm{N}=$ nucleus.

Figure 6: Transmission electron microscopy images of non-Kupffer cells in liver sections from rats $1 \mathrm{~h}$ to 90 day after nanoceria infusion. Arrow points to nanoceria agglomerations in an endothelial cell at $1 \mathrm{~h}(\mathrm{~A})$, hepatic stellate cells from day 90 (B) [and B1. Maybe these should be B1 and B2], and a hepatocyte (C). (D) Illustrates the absence of nanoceria in the bile duct (labeled as B) in the periportal region of a liver section taken 90 days after infusion. A nearby Kupffer cell is identified by an arrow. $\mathrm{N}=$ nucleus, $\mathrm{E}=$ endothelial cell, $\mathrm{S}=$ stellate cell.

Figure 7: Transmission electron microscopy images of granulomata in liver from nanoceria-infused rats 30 days (A) and 90 days (B) after infusion with ceria-containing Kupffer cells (arrows). (C) Detailed image of nanoceria aggregates showing heterogeneity in size and shape of the nanoceria particles; HRTEM/STEM image showing heterogeneity of ceria crystals in a 90-day infused sample (C1). (D) Nanoceria retained their cubic shape on day 90 as viewed in STEM mode (upper). The red line points to the surface and the blue line points to the core or the bulk of ceria crystals. EELS spectrum data showing surface-to-core difference in the M5/M4 peak intensity of the ceria crystal (lower part of the frame). EELS = electron energy loss spectroscopy; HRTEM = high-resolution transmission electron microscopy; STEM = scanning transmission electron microscope.

Figure 8: Nanoceria induced cell kinetic changes. Increased liver cell apoptosis and liver cell proliferation after nanoceria infusion is illustrated by TUNEL reaction (A) and PCNA assay (B). Asterisk indicates statistical difference between treated and control groups.

Figure 9: Nanoceria-induced apoptosis in the subacute groups is illustrated. The caspase-3-positive cells are indicated by the green-colored stain in nanoceria-infused rats (B, day 30 and D, day 90), which contrast sharply with the controls (A, day 30 and C, day 90). All nuclei are stained blue with diamidino-2-phenylindole. Magnification is $400 \mathrm{x}$.

Figure 10: Nanoceria induced changes in serum ALT level. An acute elevation after nanoceria infusion subsided in the subacute group. The difference between nanoceria treated and control rats was not statistically different. 
Figure 1.
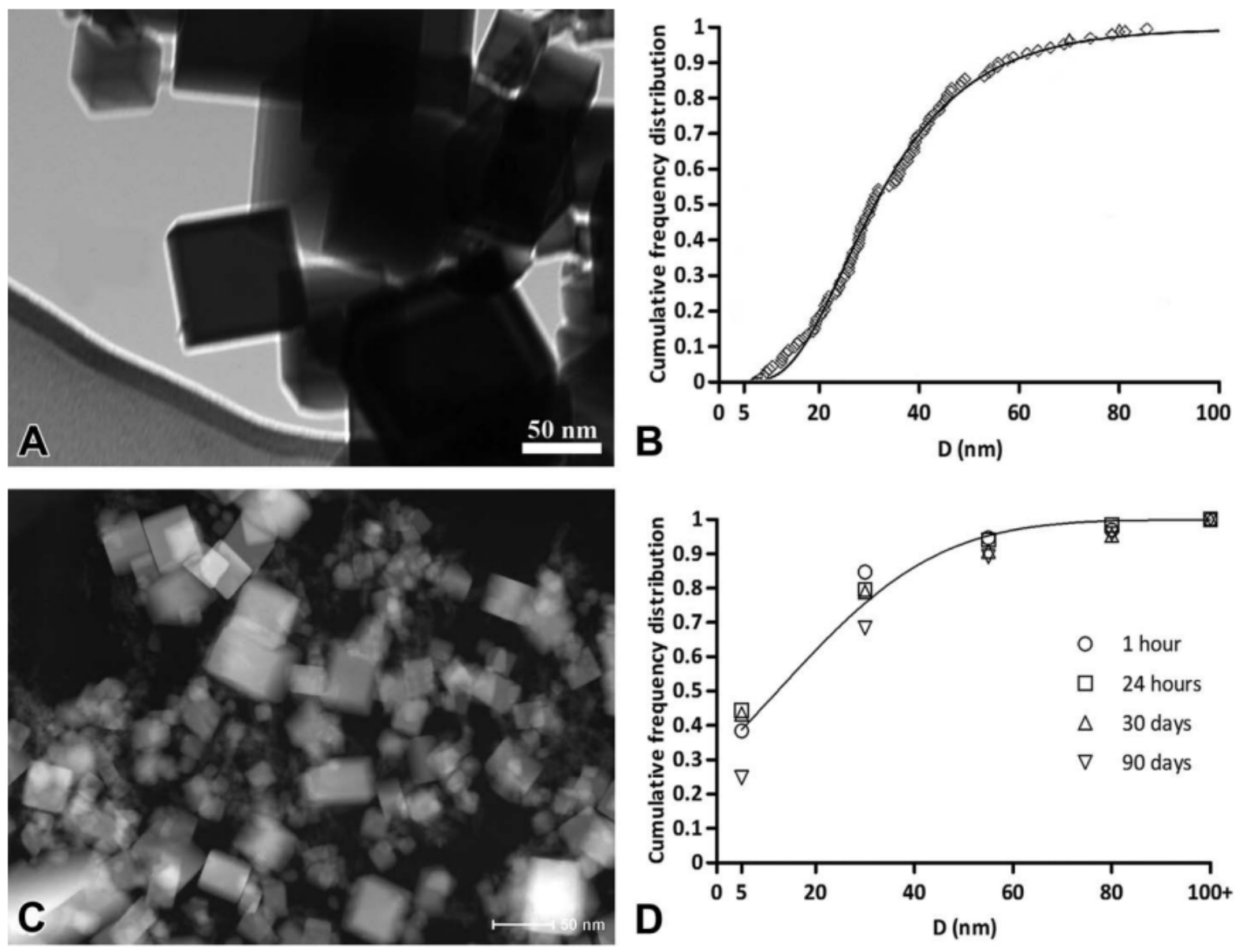
Figure 2.
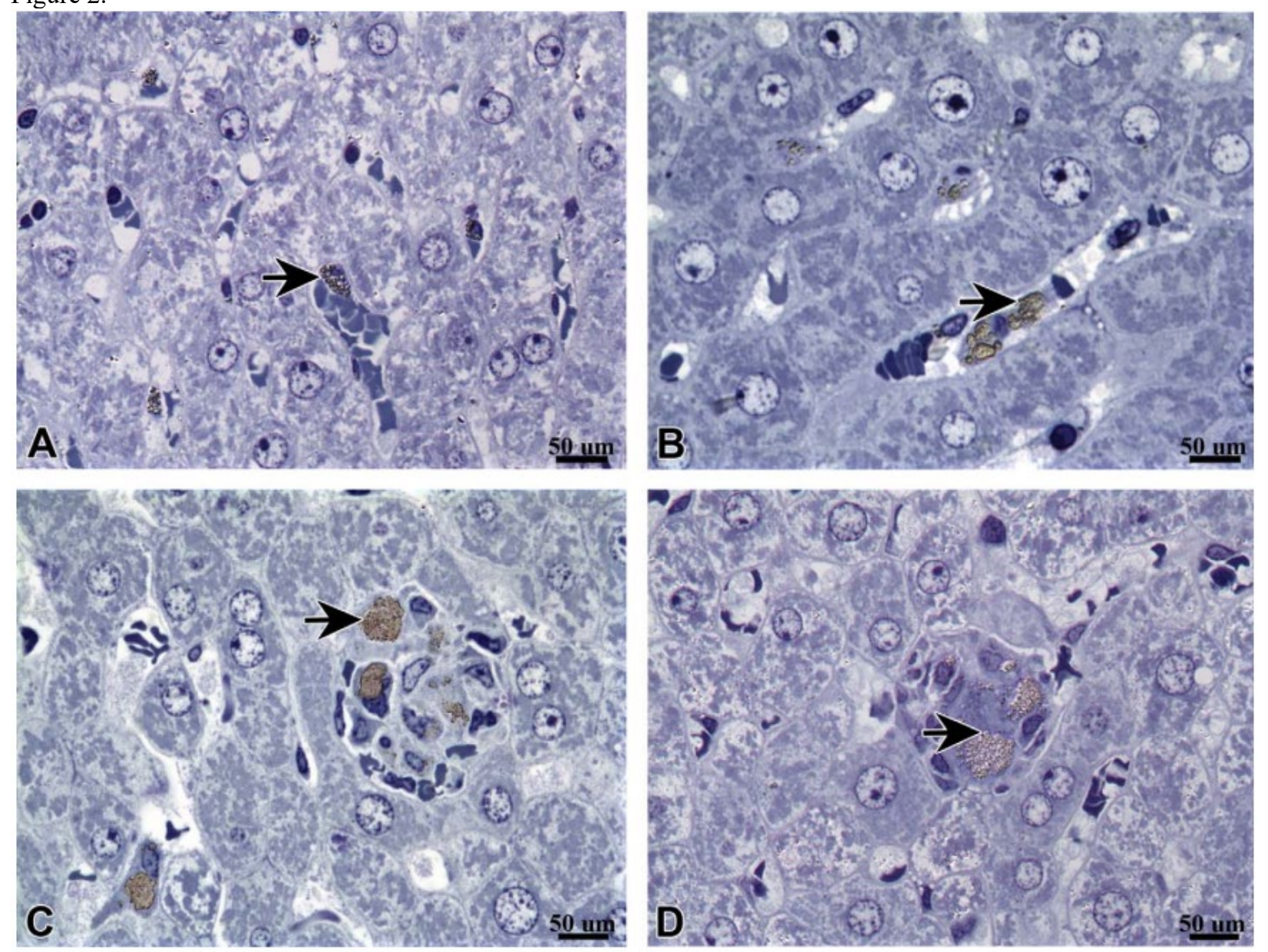
Figure 3.
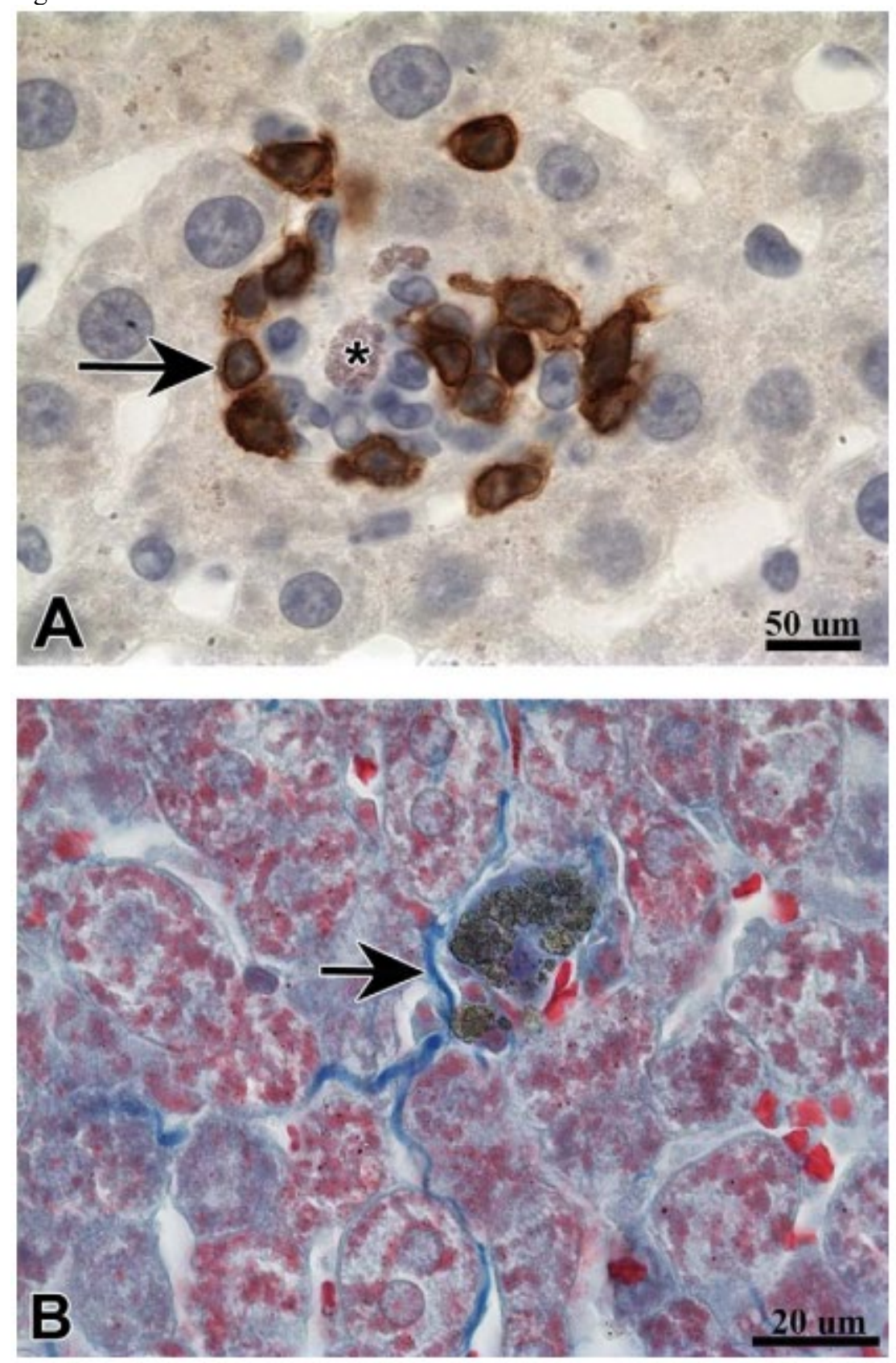
Figure 4.

$\mathrm{CD}^{+}{ }^{+} \mathrm{T}$ cell count

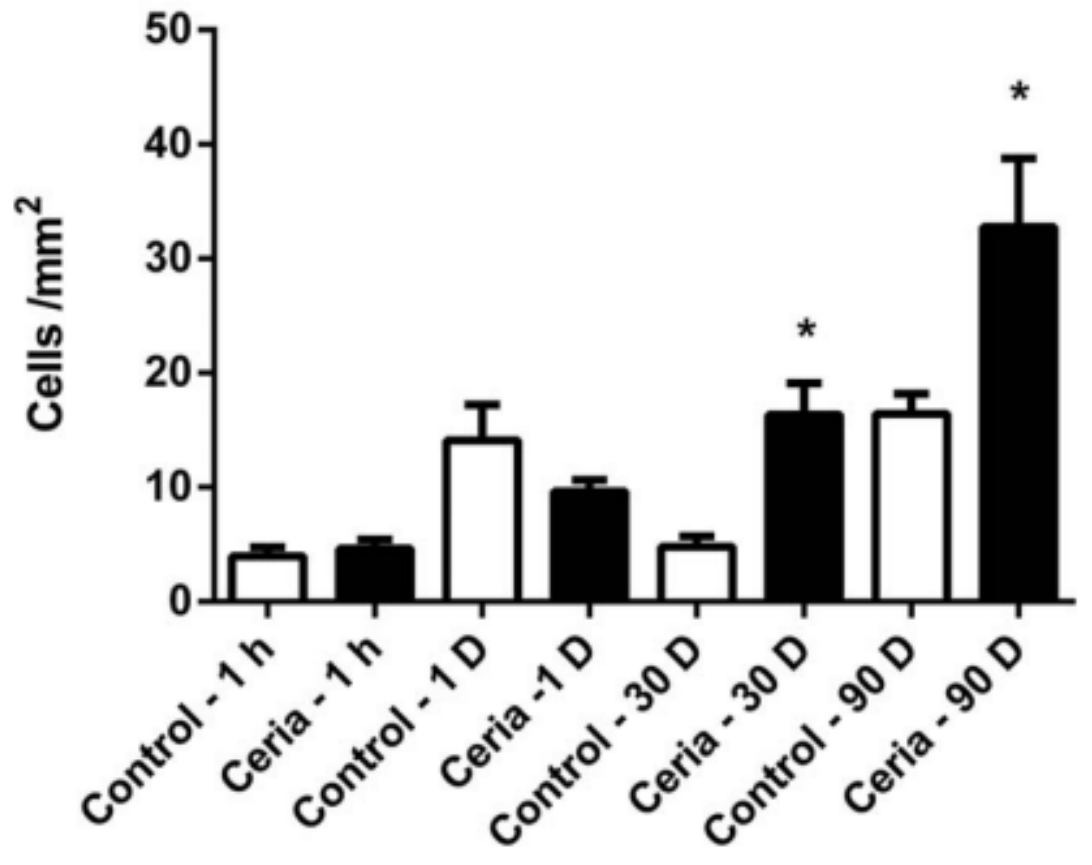


Figure 5.
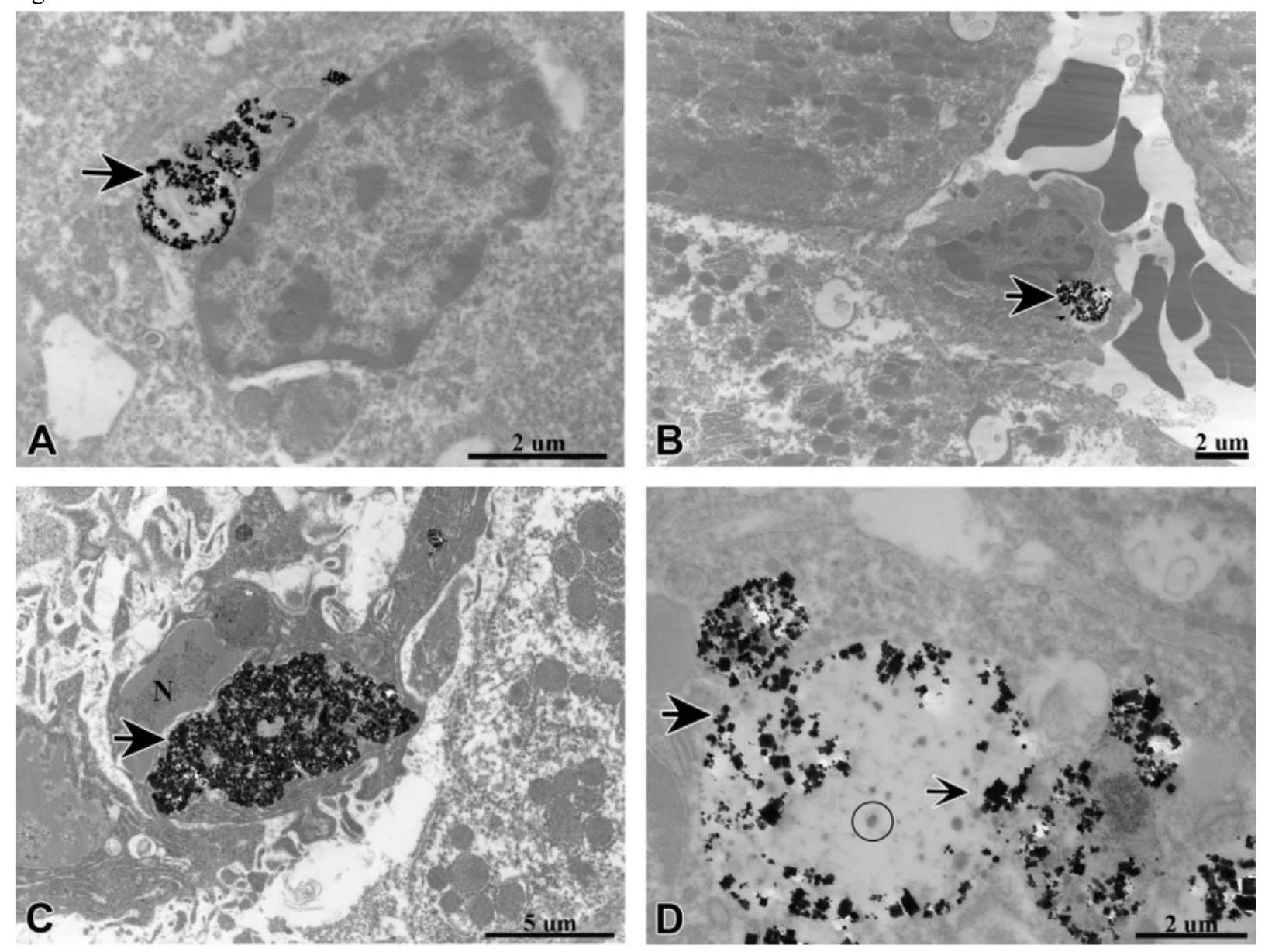
Figure 6.
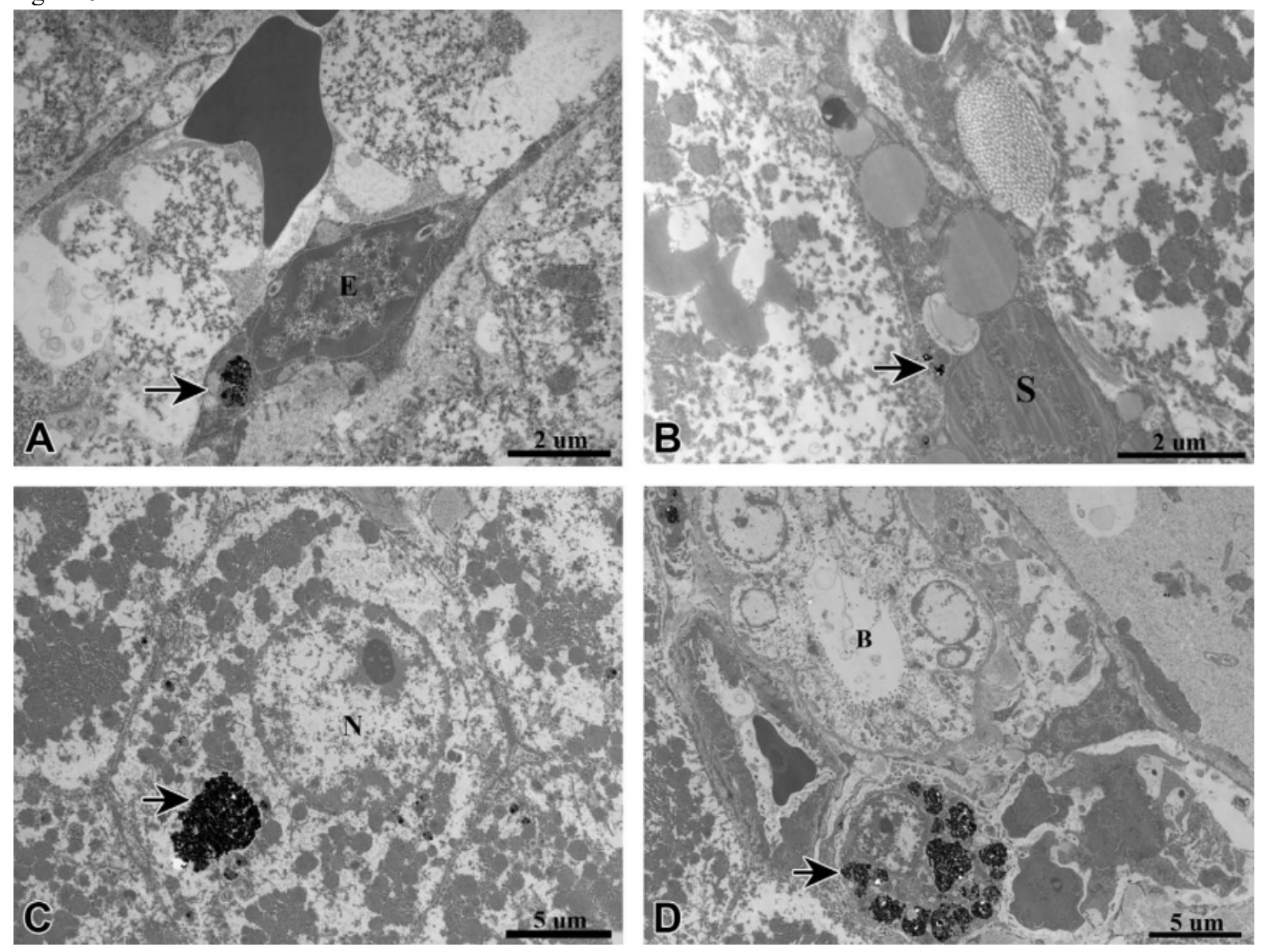
Figure 7.
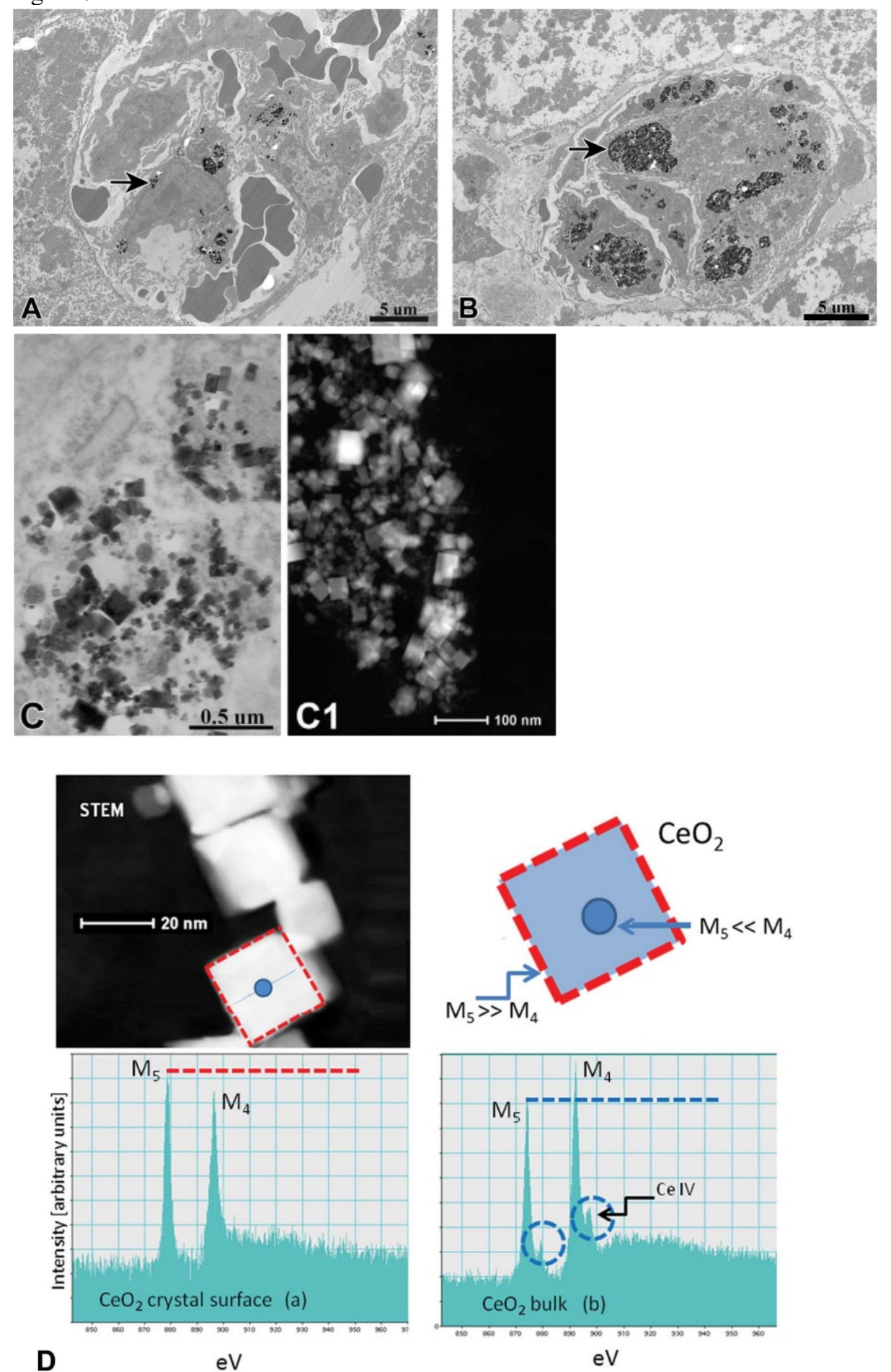
Figure 8.

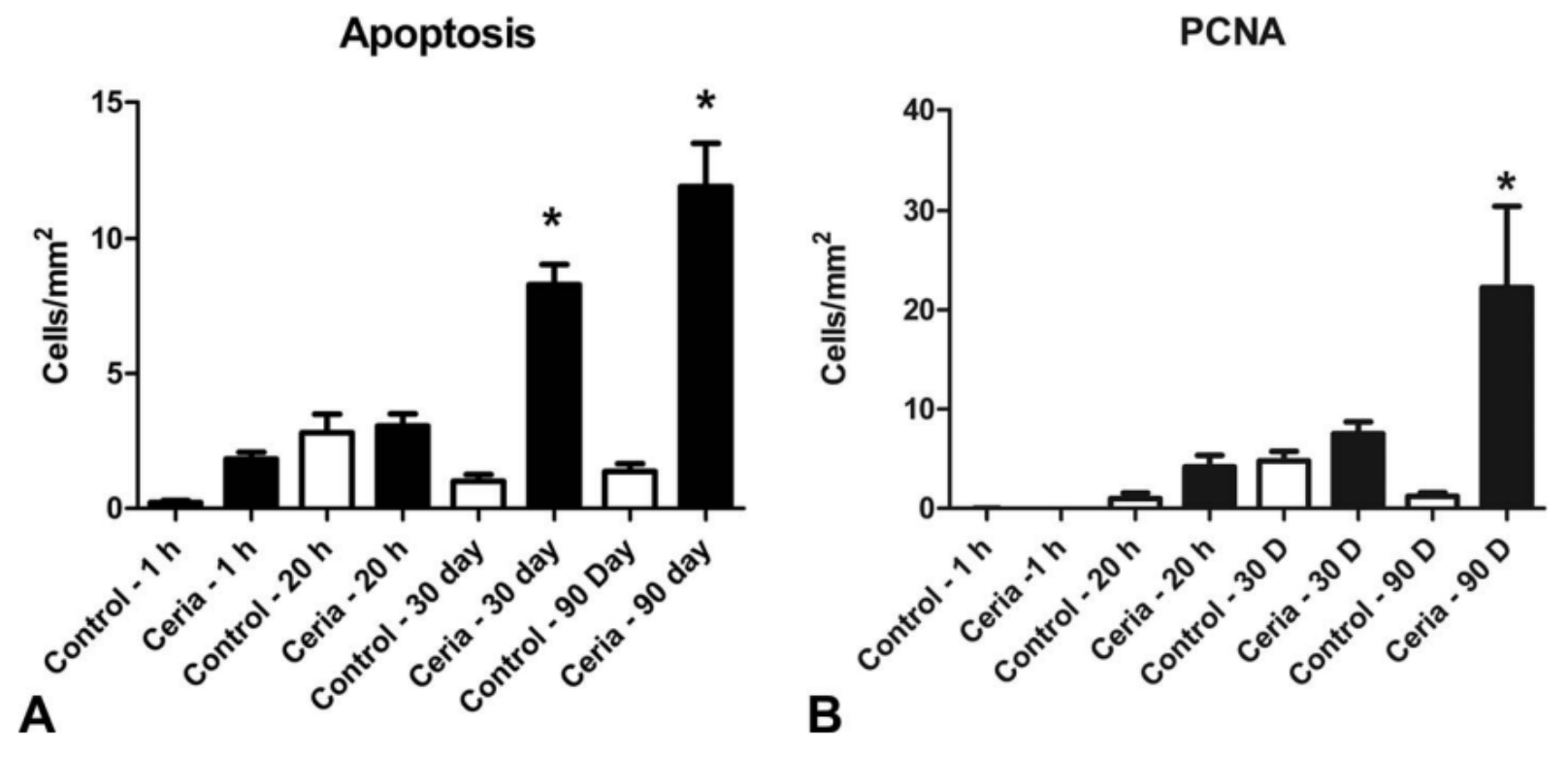


Figure 9.
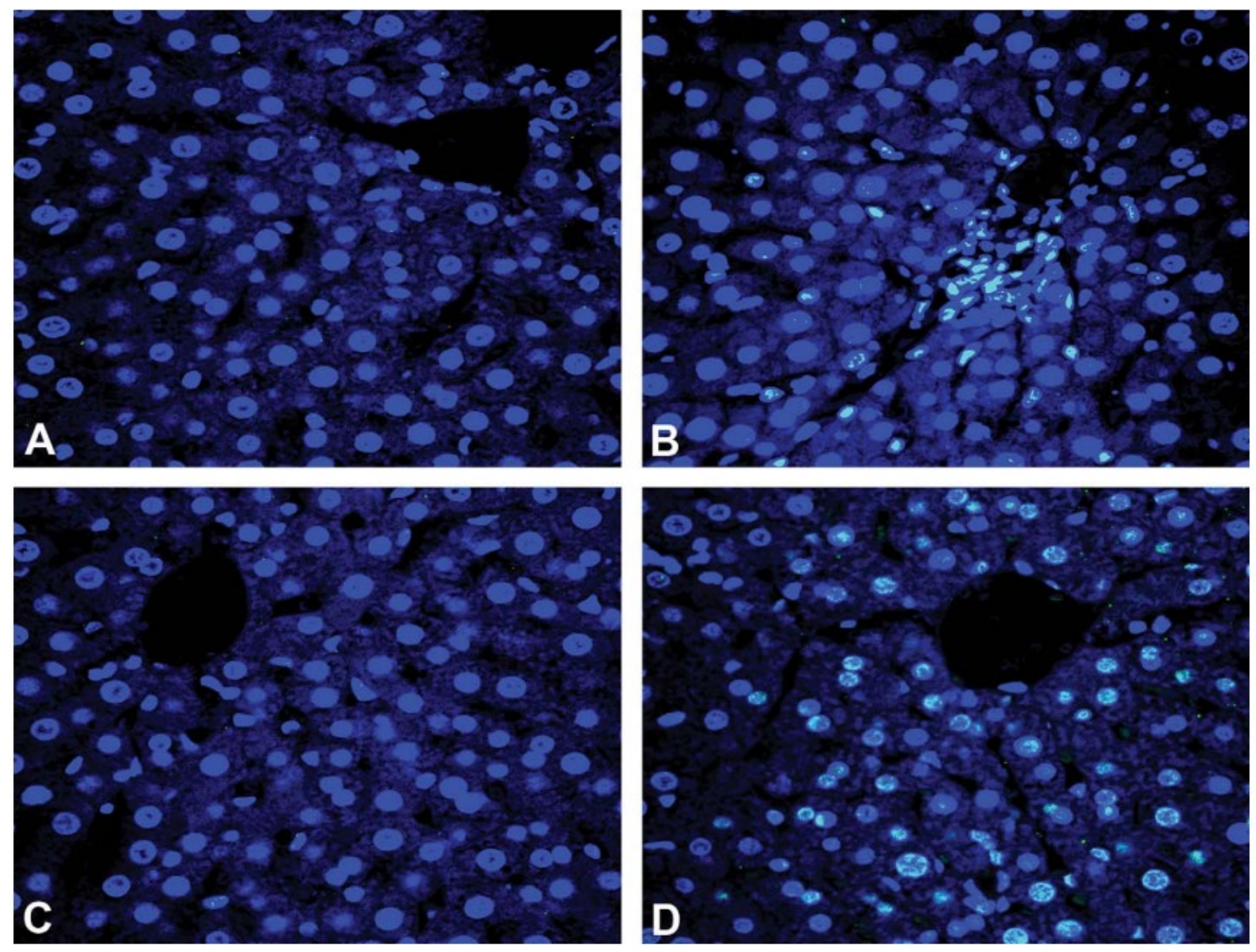
Figure 10.

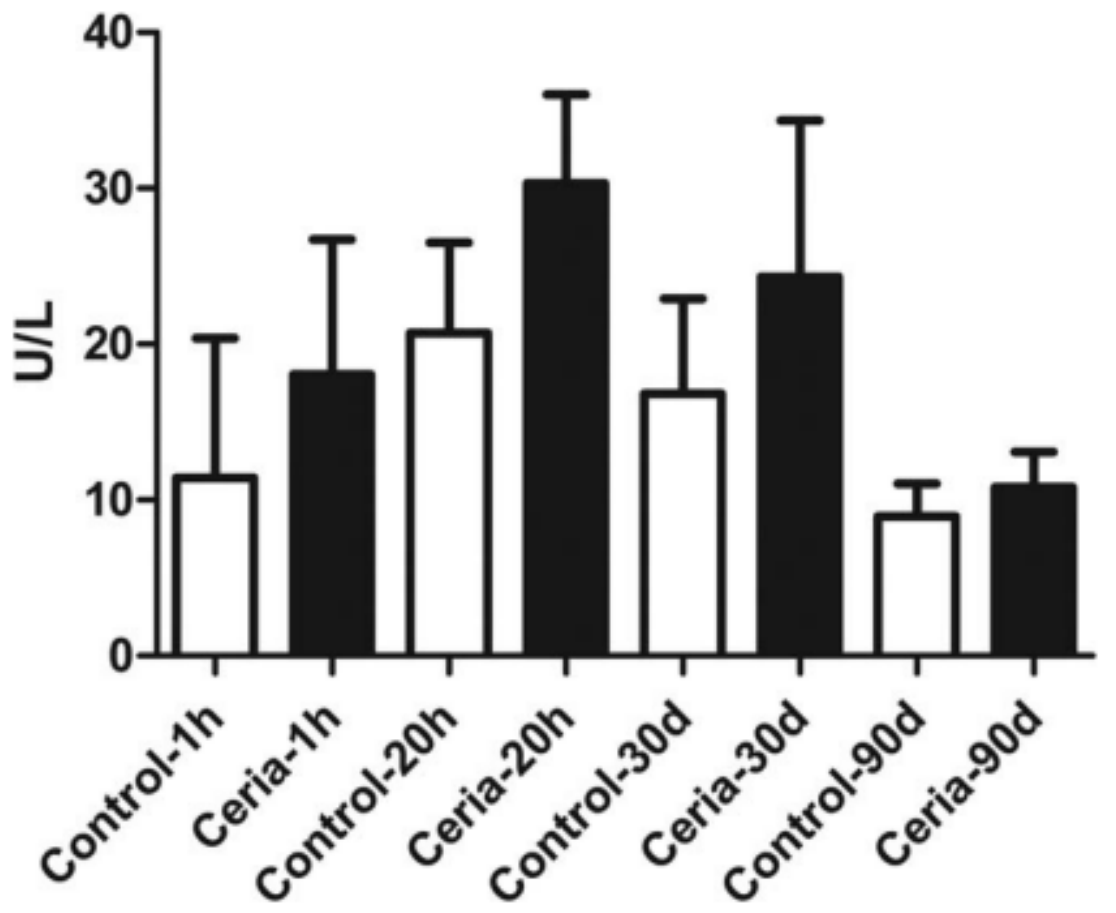

